\title{
CORERSPOINDENTCE
}

\section{RECENT DISCOVERIES IN THE SALT RANGE OF THE PUNJAB.}

Sir,-Having already trespassed upon your space with regard to this subject, I beg leave to add a few necessary words, because the discoveries already noticed (GEoL. Mag. March and May, 1886) have since extended to further recognition, by Dr. Warth and Mr. R. D. Oldham, of the continuation of the boulder beds of the original "Olive Group" westwards-these being identified by their Conulariacontaining pebble layer in a position entirely different from that which my own acquaintance with the Range would have led me to expect.

My contention has been that the boulder beds with the Conularia layer in the east of the Range, occupying a position immediately beneath the Eocene limestone, occupied a different horizon from that of other boulder beds of somewhat similar and somewhat different character, in the west of the Range, which had their place with the lowest members of the series amongst Silurian or other old Palæozoic rocks.

The recent discovery of the same Conularia-layer underlying a group of sandstones, next below the Carboniferous Limestone, must modify my previous views, and I feel the more inclined to abandon the contention above stated, were it even to involve identification of the eastern and western boulder-beds as upon one and the same horizon, in consequence of the probability that a coincident unconformity, till quite lately undetected, intervenes between these boulder beds and the older groups of the Range, its place being traceable by means of the boulder-beds with Conularia pebbles.

Without the evidence of the subsequently-discovered fossiliferous layer, or that of the associated discordance, the extension of a part of the original "Olive Group" westwards at the higher level appears to have been taken by me as representative of the whole, there being another dark-coloured zone amongst the lower groups, to which soft dark rocks could be referred when low down in the series.

The correction which it is expected will now be applied to previous classifications of the Salt Range rocks is of great interest in connexion with the geology of the Punjab, and I refer to it, so far as my own published views to the contrary are concerned, gladly accepting new light thrown upon the subject from reliable sources, but as far as possible refraining from forestalling the full announcement of details to be looked for from those who have added these important discoveries to our knowledge of the Salt Range series, a series of such complexity that additional facts of detail cropping up here or there might almost have been anticipated. A. B. Wrise.

June 10th, 1887 .

P.S.-Since writing the above I have seen Dr. Warth's account of his discovery alluded to (Records Geol. Surv. Ind. vol. xx. pt. 2, p. 117), and find therein much with which I can agree. 